\title{
LEVEL II SCOUR ANALYSIS FOR BRIDGE 42 (RANDVT00120042) on STATE HIGHWAY 12, crossing the THIRD BRANCH WHITE RIVER, RANDOLPH, VERMONT
}

U.S. Geological Survey Open-File Report 96-187

Prepared in cooperation with

VERMONT AGENCY OF TRANSPORTATION and

FEDERAL HIGHWAY ADMINISTRATION 


\section{LEVEL II SCOUR ANALYSIS FOR BRIDGE 42 (RANDVT00120042) on STATE HIGHWAY 12, crossing the THIRD BRANCH WHITE RIVER, RANDOLPH, VERMONT}

By SCOTT A. OLSON and MATTHEW A. WEBER

U.S. Geological Survey

Open-File Report 96-187

Prepared in cooperation with

VERMONT AGENCY OF TRANSPORTATION

and

FEDERAL HIGHWAY ADMINISTRATION 


\title{
U.S. DEPARTMENT OF THE INTERIOR BRUCE BABBITT, Secretary
}

\author{
U.S. GEOLOGICAL SURVEY \\ Gordon P. Eaton, Director
}

For additional information write to:

District Chief

U.S. Geological Survey 361 Commerce Way

Pembroke, NH 03275-3718
Copies of this report may be purchased from:

U.S. Geological Survey Earth Science Information Center Open-File Reports Section Box 25286, MS 517 Federal Center

Denver, CO 80225 


\section{CONTENTS}

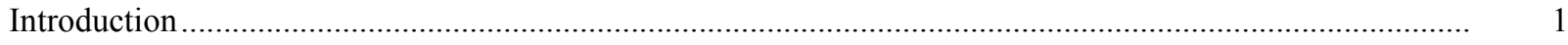

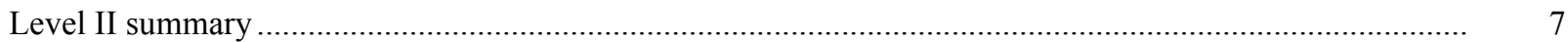

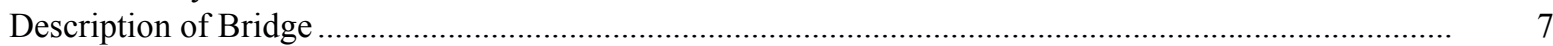

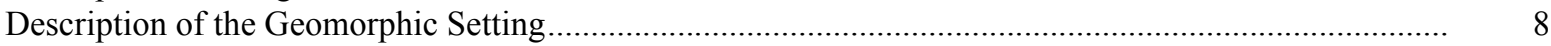

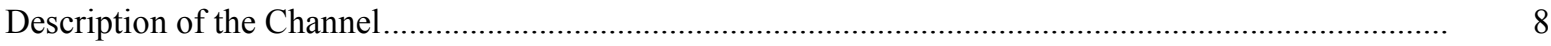

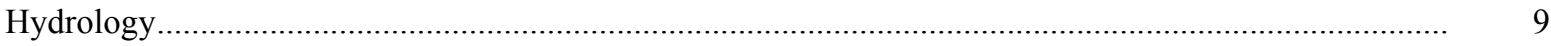

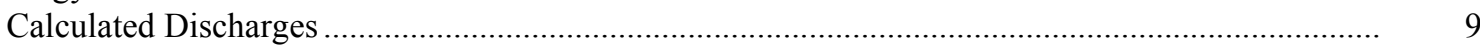

Description of the Water-Surface Profile Model (WSPRO) Analysis ......................................................... 10

Cross-Sections Used in WSPRO Analysis ......................................................................................

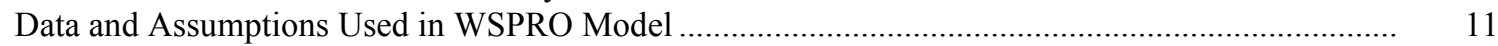

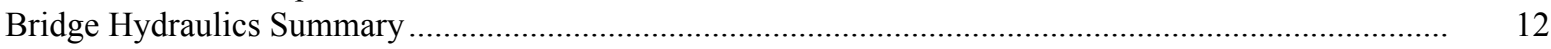

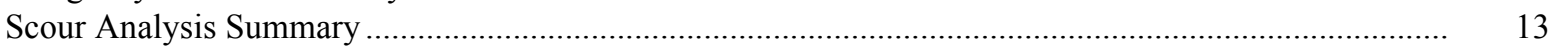

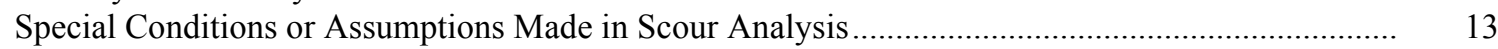

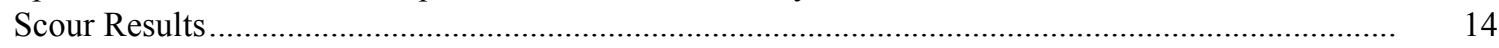

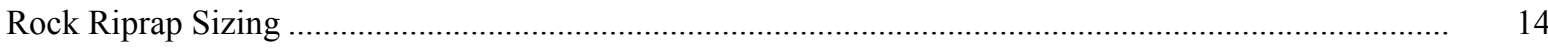

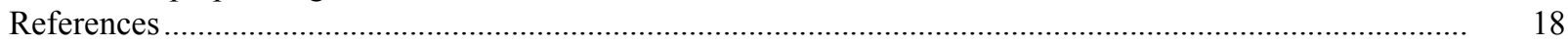

Appendixes:

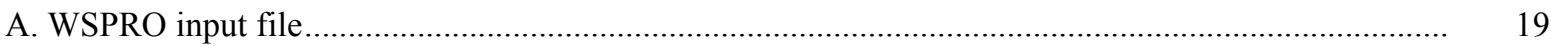

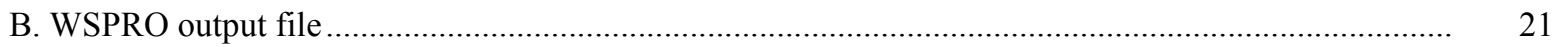

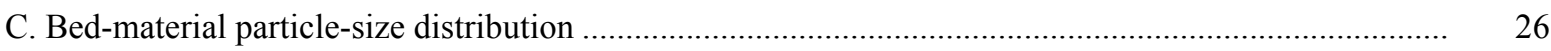

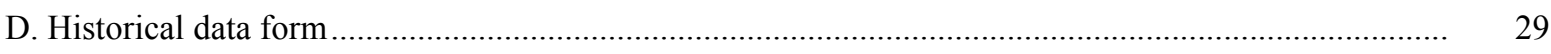

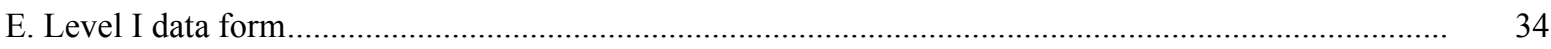

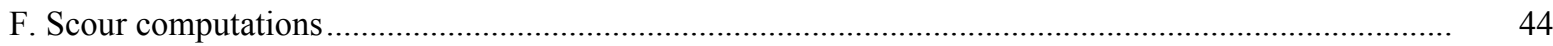

\section{FIGURES}

1. Map showing location of study area on USGS $1: 24,000$ scale map .......................................................

2. Map showing location of study area on Vermont Agency of Transportation town
highway map

3. Structure RANDVT00120042 viewed from upstream (August 3, 1994) ……................................................ 5

4. Downstream channel viewed from structure RANDVT00120042 (August 3, 1994)................................. 5

5. Upstream channel viewed from structure RANDVT00120042 (August 3, 1994). ...................................... 6

6. Structure RANDVT00120042 viewed from downstream (August 3, 1994).............................................. 6

7. Water-surface profiles for the 100- and 500-year discharges at structure

RANDVT00120042 on State Highway 12, crossing the Third Branch White River,

Randolph, Vermont.

8. Scour elevations for the 100- and 500-year discharges at structure

RANDVT00120042 on State Highway 12, crossing the Third Branch White River,

Randolph, Vermont.

\section{TABLES}

1. Remaining footing/pile depth at abutments for the 100-year discharge at structure

RANDVT00120042 on State Highway 12, crossing the Third Branch White River,

Randolph, Vermont.

2. Remaining footing/pile depth at abutments for the 500-year discharge at structure

RANDVT00120042 on State Highway 12, crossing the Third Branch White River,

Randolph, Vermont 


\begin{tabular}{|c|c|c|}
\hline Multiply & By & To obtain \\
\hline \multicolumn{3}{|c|}{ Length } \\
\hline inch (in.) & 25.4 & millimeter (mm) \\
\hline foot $(\mathrm{ft})$ & 0.3048 & $\operatorname{meter}(\mathrm{m})$ \\
\hline mile (mi) & 1.609 & kilometer (km) \\
\hline \multicolumn{3}{|c|}{ Slope } \\
\hline foot per mile ( $\mathrm{ft} / \mathrm{mi})$ & 0.1894 & meter per kilometer $(\mathrm{m} / \mathrm{km})$ \\
\hline \multicolumn{3}{|c|}{ Area } \\
\hline square mile $\left(\mathrm{mi}^{2}\right)$ & 2.590 & square kilometer $\left(\mathrm{km}^{2}\right)$ \\
\hline \multicolumn{3}{|c|}{ Volume } \\
\hline cubic foot $\left(\mathrm{ft}^{3}\right)$ & $\begin{array}{l}0.02832 \\
\text { Velocity and Flow }\end{array}$ & cubic meter $\left(\mathrm{m}^{3}\right)$ \\
\hline foot per second $(\mathrm{ft} / \mathrm{s})$ & 0.3048 & meter per second $(\mathrm{m} / \mathrm{s})$ \\
\hline cubic foot per second $\left(\mathrm{ft}^{3} / \mathrm{s}\right)$ & 0.02832 & cubic meter per second $\left(\mathrm{m}^{3} / \mathrm{s}\right)$ \\
\hline $\begin{array}{l}\text { cubic foot per second per } \\
\text { square mile } \\
{\left[\left(\mathrm{ft}^{3} / \mathrm{s}\right) / \mathrm{mi}^{2}\right]}\end{array}$ & 0.01093 & $\begin{array}{l}\text { cubic meter per } \\
\text { second per square } \\
\text { kilometer }\left[\left(\mathrm{m}^{3} / \mathrm{s}\right) / \mathrm{km}^{2}\right]\end{array}$ \\
\hline
\end{tabular}

OTHER ABBREVIATIONS

$\begin{array}{lrlr}\mathrm{BF} & \text { bank full } & \text { LWW } & \text { left wingwall } \\ \mathrm{cfs} & \text { cubic feet per second } & \text { MC } & \text { main channel } \\ \mathrm{D}_{50} & \text { median diameter of bed material } & \text { RAB } & \text { right abutment } \\ \mathrm{DS} & \text { downstream } & \text { RABUT } & \text { face of right abutment } \\ \mathrm{elev} & \text { elevation } & \text { RB } & \text { right bank } \\ \mathrm{f} / \mathrm{p} & \text { flood plain } & \text { ROB } & \text { right overbank } \\ \mathrm{ft} & \text { square feet } & \text { RWW } & \text { right wingwall } \\ \mathrm{ft} / \mathrm{ft} & \text { feet per foot } & \text { TH } & \text { town highway } \\ \mathrm{JCT} & \text { junction } & \text { UB } & \text { under bridge } \\ \mathrm{LAB} & \text { left abutment } & \text { US } & \text { upstream } \\ \mathrm{LABUT} & \text { face of left abutment } & \text { USGS } & \text { United States Geological Survey } \\ \text { LB } & \text { left bank } & \text { VTAOT Vermont Agency of Transportation } \\ \text { LOB } & \text { left overbank } & \text { WSPRO } & \text { water-surface profile model }\end{array}$

In this report, the words "right" and "left" refer to directions that would be reported by an observer facing downstream. Sea level: In this report, "sea level" refers to the National Geodetic Vertical Datum of 1929-- a geodetic datum derived from a general adjustment of the first-order level nets of the United States and Canada, formerly called Sea Level Datum of 1929.

In the appendices, the above abbreviations may be combined. For example, USLB would represent upstream left bank. 


\title{
LEVEL II SCOUR ANALYSIS FOR BRIDGE 42 (RANDVT00120042) ON STATE HIGHWAY 12, CROSSING THE THIRD BRANCH WHITE RIVER, RANDOLPH, VERMONT
}

\author{
By Scott A. Olson and Matthew A. Weber
}

\section{INTRODUCTION}

This report provides the results of a detailed Level II analysis of scour potential at structure RANDVT00120042 on State Highway 12 crossing the Third Branch White River, Randolph, Vermont (figures 1-8). A Level II study is a basic engineering analysis of the site, including a quantitative analysis of stream stability and scour (U.S. Department of Transportation, 1993). A Level I study is included in Appendix E of this report. A Level I study provides a qualitative geomorphic characterization of the study site. Information on the bridge available from VTAOT files was compiled prior to conducting Level I and Level II analyses and can be found in Appendix D.

The site is in the Green Mountain physiographic division of central Vermont in the town of Randolph. The $61.9-\mathrm{mi}^{2}$ drainage area is in a predominantly rural drainage basin. In the vicinity of the study site, the left and right banks have moderate tree cover with residential and commercial buildings on the overbank areas. 
In the study area, the Third Branch White River has a sinuous channel with a slope of approximately $0.013 \mathrm{ft} / \mathrm{ft}$, an average channel top width of $133 \mathrm{ft}$ and an average channel depth of $5 \mathrm{ft}$. The predominant channel bed material is gravel with a median grain size ( $\left.\mathrm{D}_{50}\right)$ of $49.6 \mathrm{~mm}(0.163 \mathrm{ft})$. Bank material is sand and gravel $\left(\mathrm{D}_{50}\right.$ is $3.08 \mathrm{~mm}$ or $\left.0.010 \mathrm{ft}\right)$. The geomorphic assessment at the time of the Level I site visits on July 8, 1994 and December 13, 1994, indicated that the reach has experienced vertical degradation. A drop structure has been constructed downstream of the bridge to prevent further degradation. In addition to the degradation of the stream bed, there is local pier scour at the bridge site as well. At the nose of the pier in the main channel, the bed is approximately three feet below the mean thalweg and two feet below the bottom of the pier footing.

The State Highway 12 crossing of the Third Branch White River is a 220-ft-long, two-lane bridge consisting of four concrete spans. The maximum span length is $57 \mathrm{ft}$. (Vermont Agency of Transportation, written commun., July 29, 1994). The bridge is supported by vertical, concrete abutments and three concrete piers. The toe of the left abutment is at the channel edge. The toe of the right abutment is set back on the right over-bank. The roadway centerline on the structure has a slight horizontal curve; however, the main channel is skewed approximately 5 degrees to the bridge. Additional details describing conditions at the site are included in the Level II Summary and Appendices D and E.

Scour depths and rock rip-rap sizes were computed using the general guidelines described in Hydraulic Engineering Circular 18 (Richardson and others, 1993). Scour depths were calculated assuming an infinite depth of erosive material and a homogeneous particle-size distribution. The scour analysis results are presented in tables 1 and 2 and a graph of the scour depths is presented in figure 8 . 


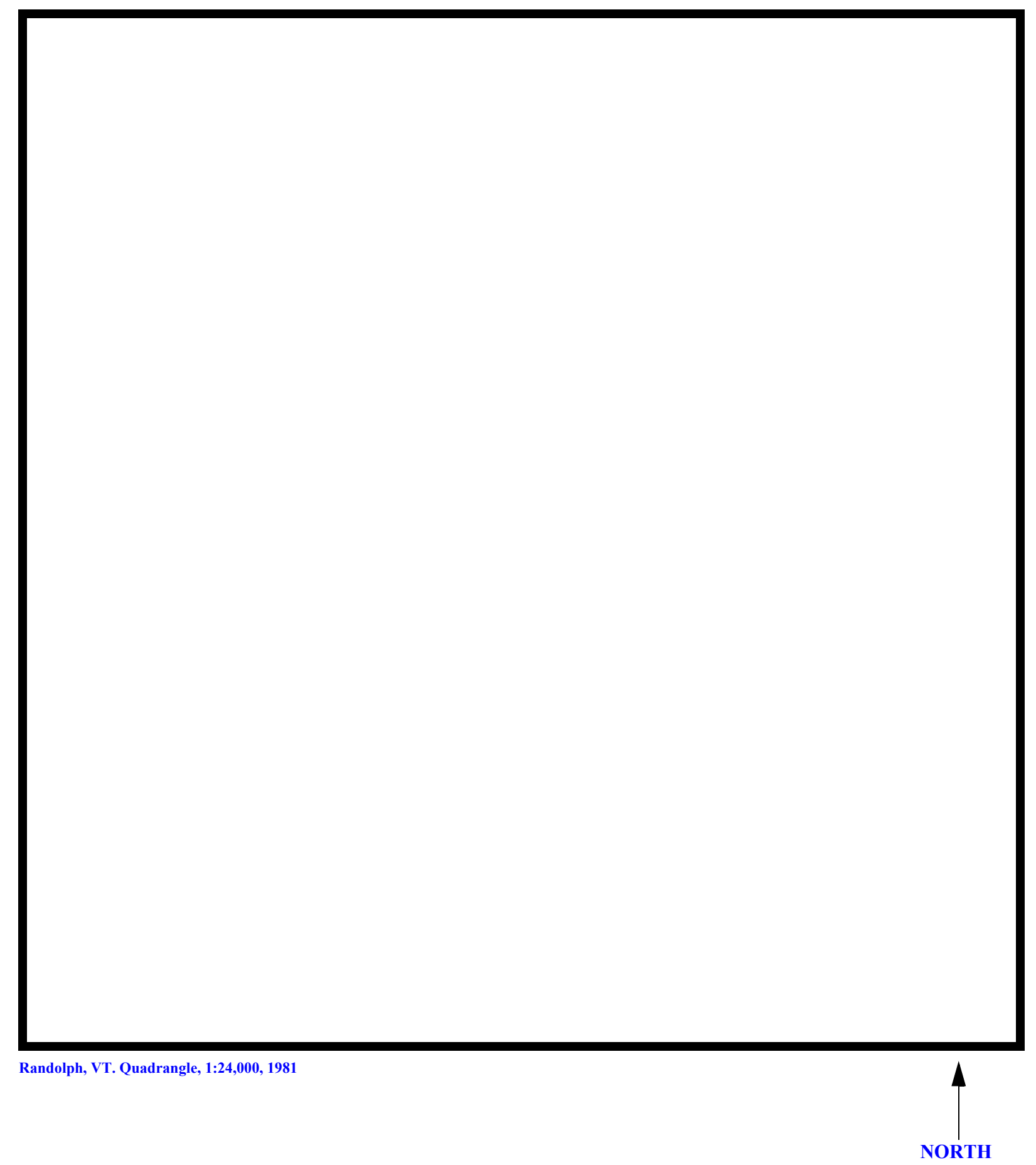

Figure 1. Location of study area on USGS 1:24,000 scale map. 
Figure 2. Location of study area on Vermont Agency of Transportation town highway map. 

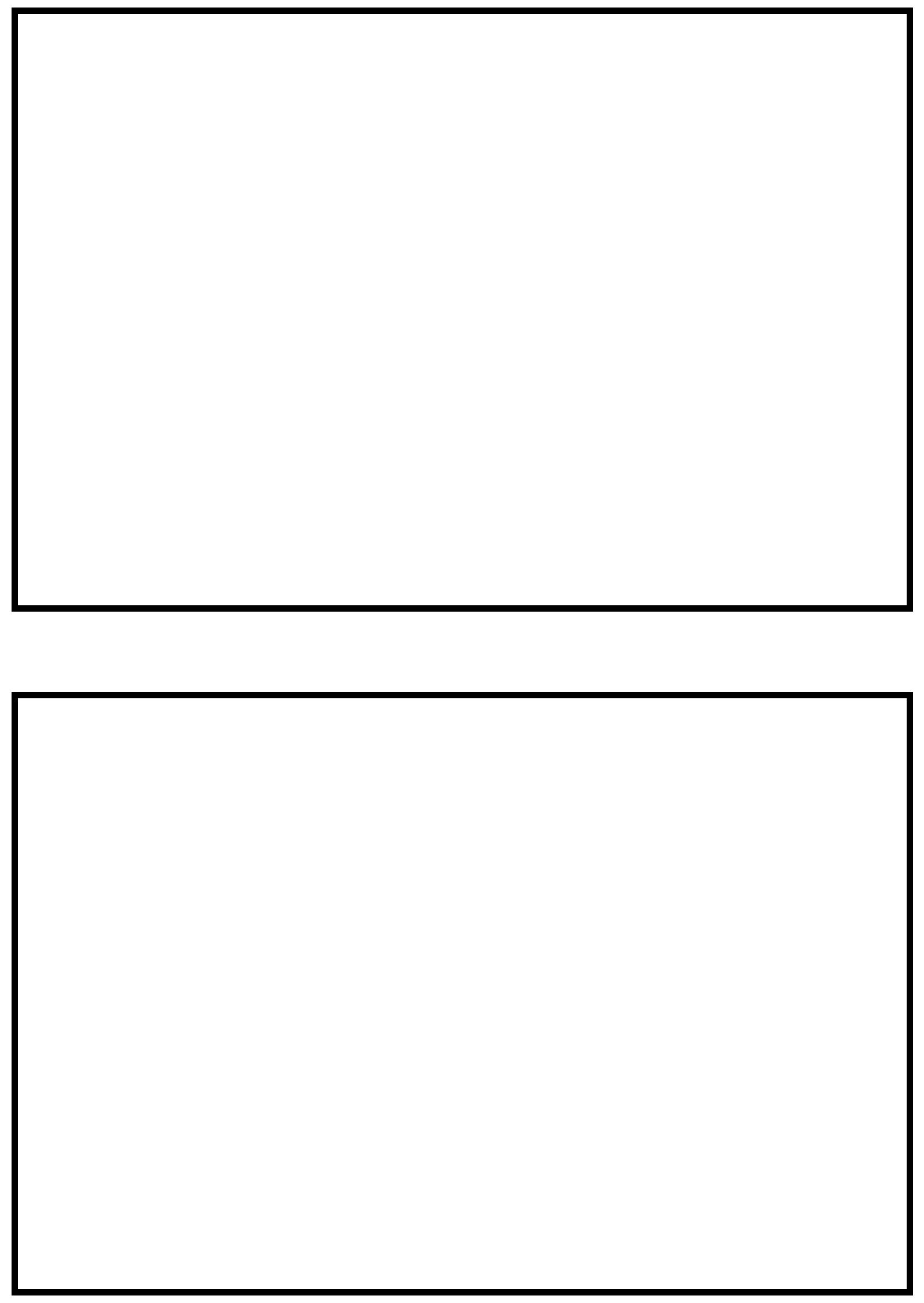

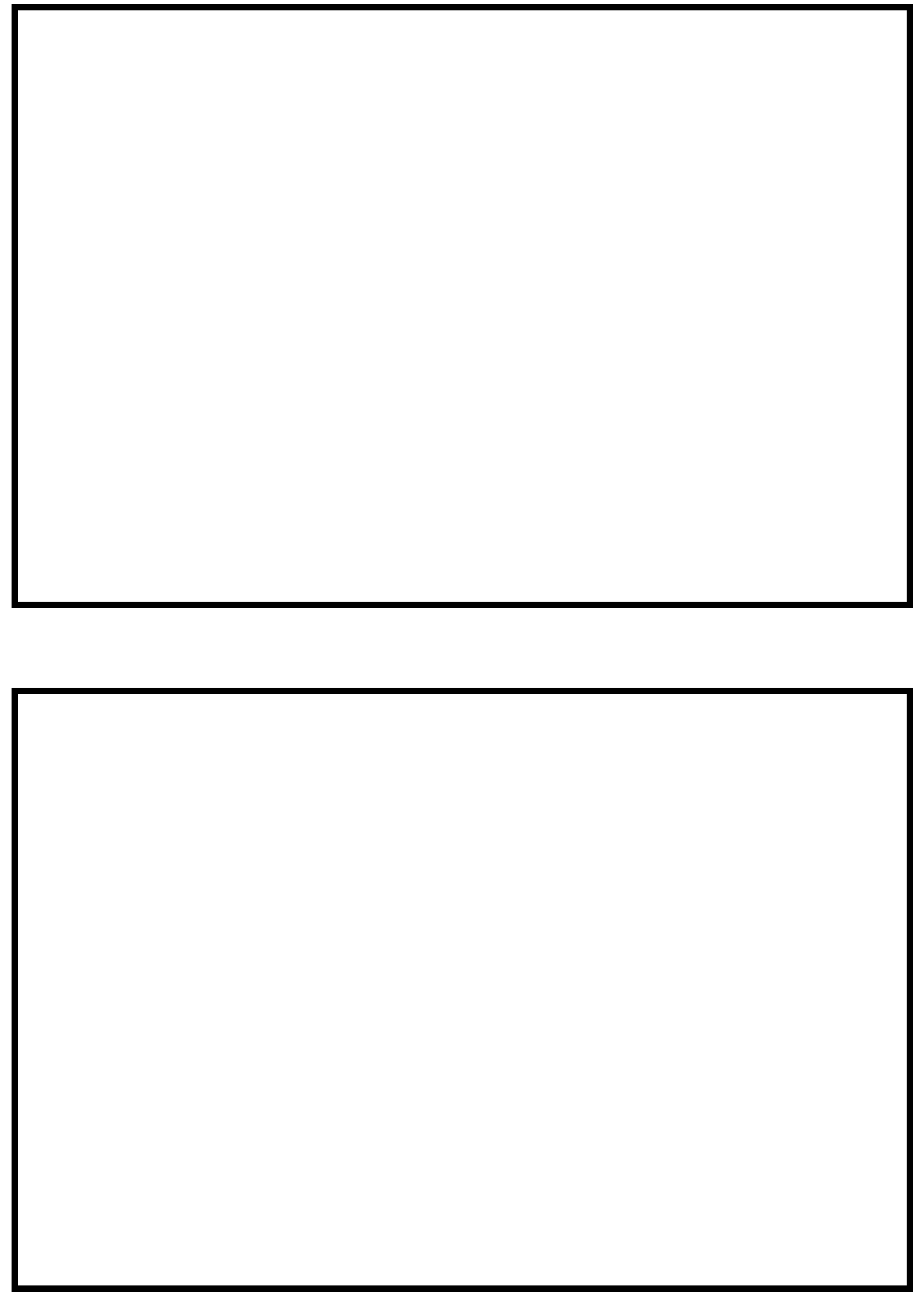


\section{LEVEL II SUMMARY}

\begin{tabular}{llllll} 
& Structure Number & RANDVT00120042 & & \multicolumn{3}{c}{ Third Branch White River } \\
Stream & & & & \\
County & Orange & Road & VT0012 & District & 04 \\
\hline
\end{tabular}

\section{Description of Bridge}

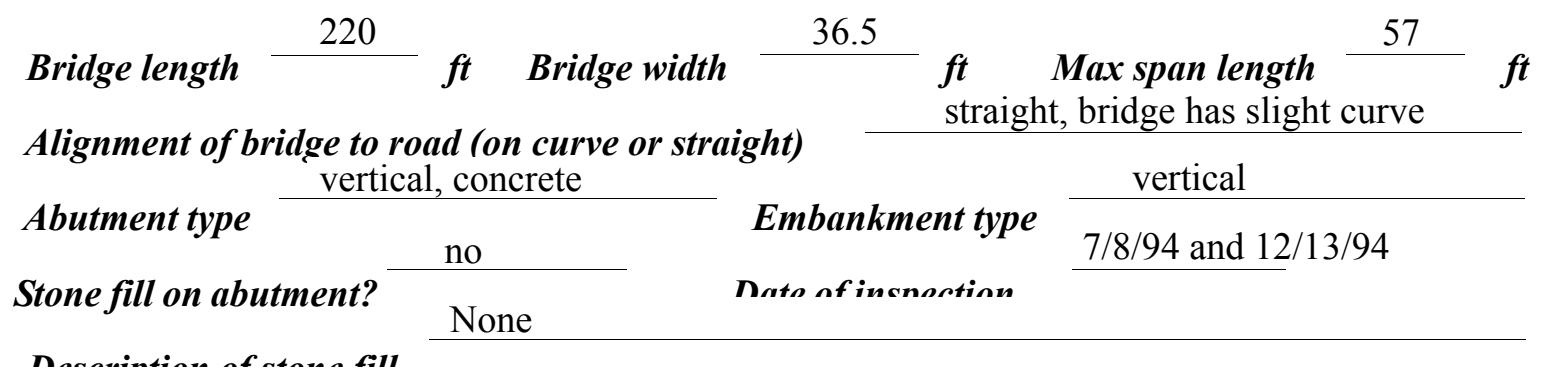

Abutments and piers are concrete. The Left abutment is at the channel edge. The right abutment is set back on the right over-bank. Only one of the three piers is in the main channel. Nose of this pier is undermined.

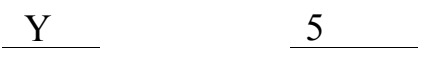

Is bridge skewed to flood flow according to N r survey? Angle

Debris accumulation on bridge at time of Level I or Level II site visit:

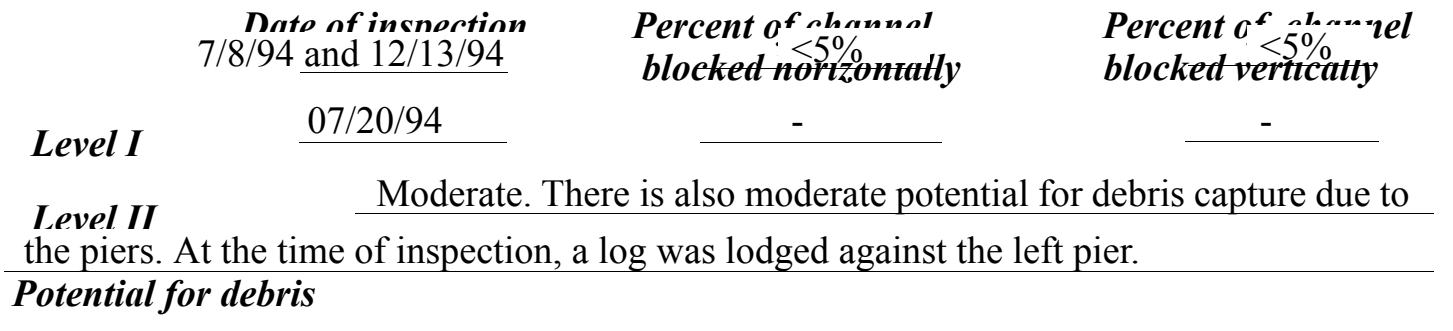

July 8, 1994 and December 13, 1994. There is a drop structure 30 feet downstream of the bridge. Doscriho anv foaturos noar ar at tho hridoo that mav, affort flow, (includo ahsorvation dato) 


\section{Description of the Geomorphic Setting}

General topography This is an upland river with moderate gradient. Floodplains are generally narrow with high stream banks.

Geomorphic conditions at bridge site: downstream (DS), upstream (US)

Date of inspection $\quad 7 / 8 / 95$ and 12/13/94

DS left: $\quad$ Steep high bank.

DS right: $\quad$ Narrow flood plain to steep high bank.

US left: $\quad$ Narrow flood plain to steep high bank.

US right: $\quad$ Narrow flood plain to steep high bank.

\section{Description of the Channel}

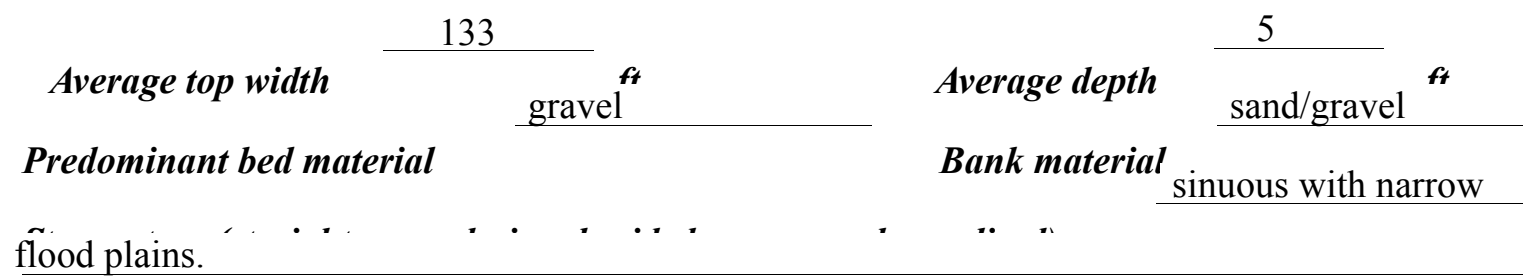

Vegetative col ${ }^{1}$ Forested.

DS left: $\quad$ Forested on immediate bank; a large building on over-bank.

DS right: $\quad$ Moderate tree cover and grass.

US left: $\quad$ Forested.

US right: $\quad$ Yes

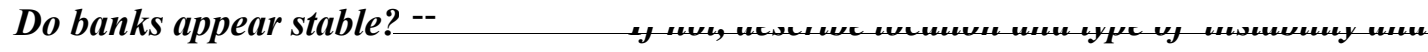

date of observation.

July 8, 1994 and

December 13, 1994. A log is lodged against the pier in the main channel. Describe any obstructions in channel and date of observation. 


\section{Hydrology}

Drainage area $\quad 61.9 \boldsymbol{m i}^{2}$

Percentage of drainage area in physiographic provinces: (approximate)

Physiographic province

Green Mountain
Percent of drainage area 100

Is drainage area considered rural or urban? — Rural Describe any significant urbanization: None.

$\mathrm{N}$

Is there a USGS gage on the stream of interest?

USGS gage description

USGS gage number

Gage drainage area

$m i^{2}$

No

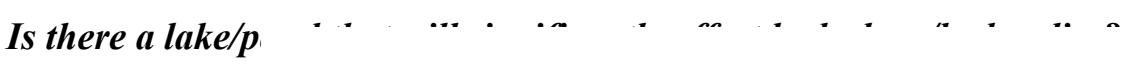

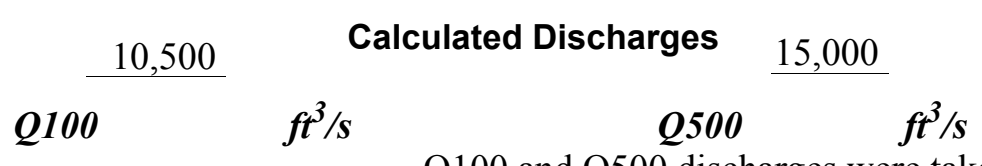

Q100 and Q500 discharges were taken from the

Federal Emergency Management Agency Flood Insurance study (Federal Emergency

Management Agency, 1991) for the Town of Randolph. 


\section{Description of the Water-Surface Profile Model (WSPRO) Analysis}

Datum for WSPRO analysis (USGS survey, sea level, VTAOT plans)

USGS survey

Datum tie between USGS survey and VTAOT plans

Subtract $442.53 \mathrm{ft}$ from USGS

datum to get VTAOT plans datum.

Description of reference marks used to determine USGS datum. $\quad$ RM1 is the top of the

first "A" in "CASHMAN" on a bronze plaque in the sidewalk at the downstream, right end of

the bridge (elev. $534.71 \mathrm{ft}$, arbitrary datum). RM2 is a the bridge rail seat immediately above

the downstream streamward end of the left abutment (elev. $527.54 \mathrm{ft}$, arbitrary datum).

\section{Cross-Sections Used in WSPRO Analysis}

\begin{tabular}{cccl}
\hline${ }^{1}$ Cross-section & $\begin{array}{c}\text { Section } \\
\text { Reference } \\
\text { Distance } \\
\text { (SRD) in feet }\end{array}$ & $\begin{array}{c}\text { 2 Cross-section } \\
\text { development }\end{array}$ & \multicolumn{1}{c}{ Comments } \\
\hline XSDS1 & 0 & 1 & \\
XSDS2 & 270 & 1 & $\begin{array}{l}\text { Section just downstream } \\
\text { of drop structure }\end{array}$ \\
DSDRP & 450 & 1 & $\begin{array}{l}\text { Exit section (at drop struc- } \\
\text { ture--submerged sharp- } \\
\text { crested weir analysis done } \\
\text { to determine water sur- } \\
\text { face) }\end{array}$ \\
USDRP & 480 & & $\begin{array}{l}\text { Downstream full valley } \\
\text { section (templated from } \\
\text { XSUS1) }\end{array}$ \\
FV & & 1 & $\begin{array}{l}\text { Bridge section } \\
\text { BRDGE }\end{array}$ \\
XSUS1 & 510 & 2 & Approach section \\
\hline
\end{tabular}

${ }^{1}$ For location of cross-sections see plan-view sketch included with Level I field form, Appendix E. For more detail on how cross-sections were developed see WSPRO input file. 


\section{Data and Assumptions Used in WSPRO Model}

Hydraulic analyses of the reach were done by use of the Federal Highway Administration's WSPRO step-backwater computer program (Shearman and others, 1986, and Shearman, 1990). The analysis reported herein reflect conditions existing at the site at the time of the study. Furthermore, in the development of the model it was necessary to assume no accumulation of debris or ice at the site. Results of the hydraulic model are presented in the Bridge Hydraulic Summary, Appendix B, and figure 7.

Channel roughness factors (Manning's " $n$ ”) used in the hydraulic model were estimated using field inspections at each cross section following the general guidelines described by Arcement, Jr. and Schneider (1989). Channel " $n$ " values for the reach ranged from 0.025 to 0.038 , and overbank " $n$ " values ranged from 0.040 to 0.103 .

A step-backwater solution could not be found at the drop structure downstream of bridge 42 . Thus, alternative methods for computing starting water surface elevations for the bridge model were necessary. The elevations were determined by a weir rating developed for the drop structure combined with an estimated rating developed for the flow on the right over-bank. To develop these rating curves, the tailwater elevations for the drop structure were needed.

To determine the tailwater elevations at the drop structure, the three cross sections surveyed downstream of the drop structure were modelled. Normal depth was assumed as the starting water surface for this initial model and was computed by use of the slope-conveyance method outlined in the User's manual for WSPRO (Shearman, 1990). The slope used was

$0.013 \mathrm{ft} / \mathrm{ft}$ which was determined from surveyed thalweg points $210 \mathrm{ft}$ and $480 \mathrm{ft}$ downstream of the drop structure. The resulting tailwater elevations for the 100-year and 500-year events were 506.5 and $508.7 \mathrm{ft}$, respectively. The crest of the drop structure is $499.9 \mathrm{ft}$.

Submerged sharp-crested weir computations (Brater and King, 1982, pp 5-4 to 5-17) were then done to determine the rating curve for headwater elevations at the drop structure. A rating of the over-bank flow right of the drop structure was also necessary. The overbank was modelled with WSPRO using the overbank geometry of the cross sections on and downstream of the drop structure. The starting water surface of this over-bank model was the drop structure tailwater. The rating developed from this crude model was graphically combined with the weir rating to determine the water surface at the upstream side of the drop structure. The 100-year and 500-year water surface elevations are 508.8 and 510.6 feet, respectively. These elevations were used as the starting water surface elevation for the bridge model. 


\section{Bridge Hydraulics Summary}

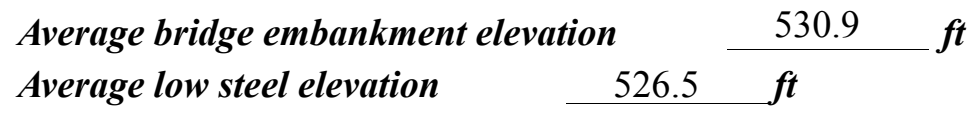

100-year discharge $\quad 10,500 \quad \mathrm{ft}^{3} / \mathrm{s}$

Water-surface elevation in bridge opening $\quad \begin{array}{lll}509.0 \quad f t \\ \end{array}$

Road overtopping? ___ N Discharge over road $-{ }^{-}, \ldots$

Area of flow in bridge opening $\quad \begin{array}{ll}1060 \quad \boldsymbol{f t}^{2} \\ -\end{array}$

$\begin{array}{lll}\text { Average velocity in bridge opening } & 9.9 \mathrm{ft} / \mathrm{s}\end{array}$

$\begin{array}{llll}\text { Maximum WSPRO tube velocity at bridge } & 14.7 & \mathrm{ft} / \mathrm{s}\end{array}$

Water-surface elevation at Approach section with bridge

Water-surface elevation at Approach section without bridge

510.0

Amount of backwater caused by bridge

$0.3 \quad$ it

500-year discharge $\quad 15,000 \quad \mathrm{ft}^{3} / \mathrm{s}$

Water-surface elevation in bridge opening

$510.8 f t$

Road overtopping? ___ N Discharge over road

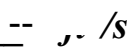

Area of flow in bridge opening $\quad 1330 \quad \mathrm{ft}^{2}$

Average velocity in bridge opening $\quad 11.3 \mathrm{ft} / \mathrm{s}$

Maximum WSPRO tube velocity at bridge 17.1_'s

Water-surface elevation at Approach section with bridge

512.0

Water-surface elevation at Approach section without bridge

Amount of backwater caused by bridge

0.3 .

Incipient overtopping discharge $f t^{3} / s$

Water-surface elevation in bridge opening

Area of flow in bridge opening $f t^{2}$ Average velocity in bridge opening Maximum WSPRO tube velocity at bridge $f t / s$

Water-surface elevation at Approach section with bridge Water-surface elevation at Approach section without bridge Amount of backwater caused by bridge it 


\section{Scour Analysis Summary}

\section{Special Conditions or Assumptions Made in Scour Analysis}

Scour depths were computed using the general guidelines described in Hydraulic Engineering Circular 18 (Richardson and others, 1993). Scour depths were calculated assuming an infinite depth of erosive material and a homogeneous particle-size distribution. The results of the scour analysis are presented in tables 1 and 2 and a graph of the scour depths is presented in figure 8 .

Contraction scour in the main channel was computed by use of the live-bed contraction scour equation (Richardson and others, 1993, p. 33, equation 16) for the 500year discharge. Contraction scour for the 100-year discharge and in the over-bank was computed by use of the clear-water contraction scour equation (Richardson and others, 1993, p.35, equation 18). For contraction scour computations, the average depth in the contracted section (AREA/TOPWIDTH) is subtracted from the depth of flow computed by the scour equation (Y2) to determine the actual amount of scour.

Abutment scour at the left abutment was computed using the Froehlich equation (Richardson and others, 1993, p. 49, equation 24). The Froehlich equation gives "excessively conservative estimates of scour depths" (Richardson and others, 1993, p. 48).

Pier scour was computed using the Colorado State University pier scour equation (Richardson and others, 1993, p. 39, equation 21). Two methods were used for determining variables for the scour computations of the pier in the main channel and the most conservative answer used. The first method used the velocity of the maximum velocity flow tube in the main channel and the pier width in the equation. The second method used the width of the pier footing since it was exposed and the velocity at the exposed footing. The velocity at the exposed footing was a depth weighted estimate of the maximum velocity flow tube (Richardson and others, 1993, p. 41, equation 23). Variables used in the equation for the over-bank pier included the pier width and the maximum velocity in the over-bank flow tubes. Only the over-bank flow tubes were used since the thalweg was not expected to shift.

Potential scour at the drop structure was not computed. However, failure of the drop structure would result is significant lowering of the bed at the bridge. 


\section{Scour Results}

$$
\text { 100-yr discharge 500-yr discharge }
$$

(Scour depths in feet)

Main channel

Live-bed scour

Clear-water scour

Depth to armoring

Left overbank

Right overbank

Local scour:

Abutment scour

Left abutment

Right abutment

Pier scour

Pier 1

Pier 2

Pier 3
19.0

0.0

11.6

7.2

0.0
23.7

$0.0-$

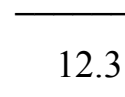

7.2

0.0
discharge

Incipient 


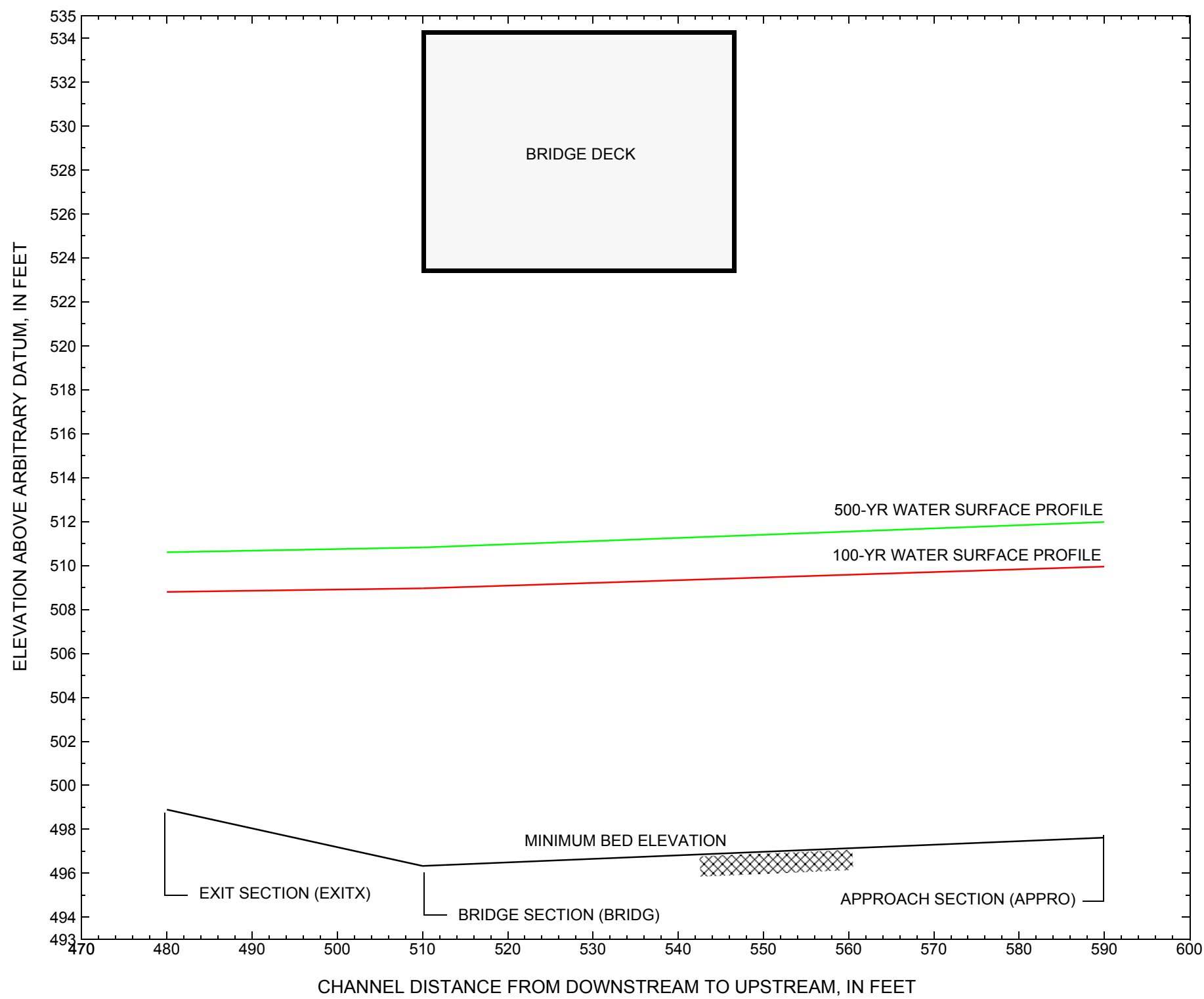

Figure 7. Water-surface profiles for the 100- and 500-yr discharges at structure RANDVT00120042 on State Highway 12, crossing the Third Branch White River, Randolph, Vermont. 


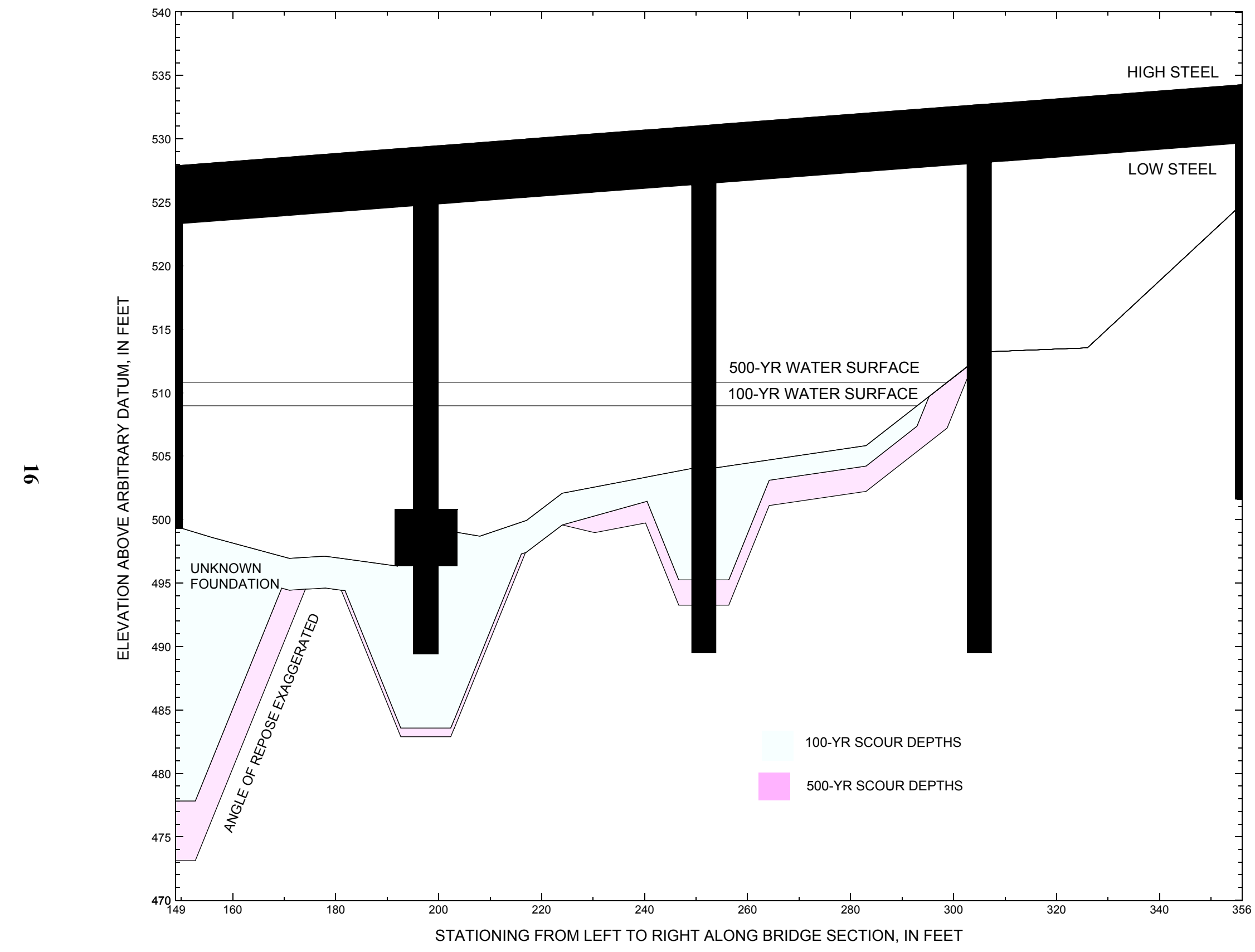

Figure 8. Scour elevations for the 100-yr and 500-yr discharges at structure RANDVT00120042 on State Highway 12, crossing the Third Branch White River, Randolph, Vermont. 
Table 1. Remaining footing/pile depth at abutments for the 100-year discharge at structure RANDVT00120042 on State Highway 12, crossing the Third Branch White River, Randolph, Vermont.

[VTAOT, Vermont Agency of Transportation; --,no data]

\begin{tabular}{|c|c|c|c|c|c|c|c|c|c|c|c|}
\hline Description & Station $^{1}$ & $\begin{array}{l}\text { VTAOT } \\
\text { minimum } \\
\text { low-chord } \\
\text { elevation } \\
\text { (feet) }\end{array}$ & $\begin{array}{c}\text { Surveyed } \\
\text { minimum } \\
\text { low-chord } \\
\text { elevation } \\
\quad \text { (feet) }\end{array}$ & $\begin{array}{l}\text { Bottom of } \\
\text { footing } \\
\text { elevation } \\
\text { (feet) }\end{array}$ & $\begin{array}{c}\text { Channel } \\
\text { elevation at } \\
\text { abutment/ } \\
\text { pier }^{2} \\
\text { (feet) }\end{array}$ & $\begin{array}{l}\text { Contraction } \\
\text { scour depth } \\
\text { (feet) }\end{array}$ & $\begin{array}{l}\text { Abutment } \\
\text { scour } \\
\text { depth } \\
\text { (feet) }\end{array}$ & $\begin{array}{l}\text { Pier } \\
\text { scour } \\
\text { depth } \\
\text { (feet) }\end{array}$ & $\begin{array}{l}\text { Depth of } \\
\text { total scour } \\
\text { (feet) }\end{array}$ & $\begin{array}{c}\text { Elevation of } \\
\text { scour }^{2} \\
\text { (feet) }\end{array}$ & $\begin{array}{c}\text { Remaining } \\
\text { footing/pile } \\
\text { depth } \\
\text { (feet) }\end{array}$ \\
\hline \multicolumn{12}{|c|}{100 -yr. discharge is 10,500 cubic-feet per second } \\
\hline Left abutment & 150 & 80.33 & -- & -- & 499.3 & 2.5 & 19.0 & -- & 21.5 & 477.8 & -- \\
\hline Pier1 & 198 & 81.76 & -- & 489.5 & 497.7 & 2.5 & -- & 11.6 & 14.1 & 483.6 & -5.9 \\
\hline Pier 2 & 252 & 83.69 & -- & 489.5 & 504.0 & 1.6 & -- & 7.2 & 8.8 & 495.2 & 5.7 \\
\hline Pier 3 & 305 & 85.63 & -- & 489.5 & 512.7 & -- & -- & -- & 0.0 & 512.7 & 23.2 \\
\hline Right abutment & 355 & 87.57 & 530.10 & 501.6 & 524.5 & -- & -- & -- & 0.0 & 524.5 & 22.9 \\
\hline
\end{tabular}

${ }^{1} \cdot$ Measured along the face of the most constricting side of the bridge.

2. Arbitrary datum for this study.

Table 2. Remaining footing/pile depth at abutments for the 500-year discharge at structure RANDVT00120042 on State Highway 12, crossing the Third Branch White River, Randolph, Vermont.

[VTAOT, Vermont Agency of Transportation; --, no data]

\begin{tabular}{|c|c|c|c|c|c|c|c|c|c|c|c|}
\hline Description & Station $^{1}$ & $\begin{array}{l}\text { VTAOT } \\
\text { minimum } \\
\text { low-chord } \\
\text { elevation } \\
\text { (feet) }\end{array}$ & $\begin{array}{c}\text { Surveyed } \\
\text { minimum } \\
\text { low-chord } \\
\text { elevation }{ }^{2} \\
\text { (feet) }\end{array}$ & $\begin{array}{c}\text { Bottom of } \\
\text { footing } \\
\text { elevation } \\
\text { (feet) }\end{array}$ & $\begin{array}{c}\text { Channel } \\
\text { elevation at } \\
\text { abutment/ } \\
\text { pier }^{2} \\
\text { (feet) }\end{array}$ & $\begin{array}{l}\text { Contraction } \\
\text { scour depth } \\
\text { (feet) }\end{array}$ & $\begin{array}{l}\text { Abutment } \\
\text { scour } \\
\text { depth } \\
\text { (feet) }\end{array}$ & $\begin{array}{l}\text { Pier } \\
\text { scour } \\
\text { depth } \\
\text { (feet) }\end{array}$ & $\begin{array}{l}\text { Depth of } \\
\text { total scour } \\
\text { (feet) }\end{array}$ & $\begin{array}{c}\text { Elevation of } \\
\text { scour }^{2} \\
\text { (feet) }\end{array}$ & $\begin{array}{c}\text { Remaining } \\
\text { footing/pile } \\
\text { depth } \\
\text { (feet) }\end{array}$ \\
\hline \multicolumn{12}{|c|}{500 -yr. discharge is 15,000 cubic-feet per second } \\
\hline Left abutment & 150 & 80.33 & -- & -- & 499.3 & 2.5 & 23.7 & -- & 26.2 & 473.1 & -- \\
\hline Pier 1 & 198 & 81.76 & -- & 489.5 & 497.7 & 2.5 & -- & 12.3 & 14.8 & 482.9 & -6.6 \\
\hline Pier 2 & 252 & 83.69 & -- & 489.5 & 504.0 & 3.6 & -- & 7.2 & 10.8 & 493.2 & 3.7 \\
\hline Pier 3 & 305 & 85.63 & -- & 489.5 & 512.7 & -- & -- & -- & 0.0 & 512.7 & 23.2 \\
\hline Right abutment & 355 & 87.57 & 530.10 & 501.6 & 524.5 & -- & -- & -- & 0.0 & 524.5 & 22.9 \\
\hline
\end{tabular}

${ }^{1 .}$ Measured along the face of the most constricting side of the bridge.

2. Arbitrary datum for this study. 


\section{SELECTED REFERENCES}

Arcement, G.J., Jr., and Schneider, V.R., 1989, Guide for selecting Manning's roughness coefficients for natural channels and flood plains: U.S. Geological Survey Water-Supply Paper 2339, 38 p.

Barnes, H.H., Jr., 1967, Roughness characteristics of natural channels: U.S. Geological Survey Water-Supply Paper 1849, 213 p.

Brater, E.F., and King, H.W., 1982, Handbook of Hydraulics, McGraw-Hill Book Company.

Brown, S.A. and Clyde, E.S., 1989, Design of riprap revetment: Federal Highway Administration Hydraulic Engineering Circular No. 11, Publication FHWA-IP-89-016, 156 p.

Federal Emergency Management Agency, 1991, Flood Insurance Study, Town of Randolph, Orange County, Vermont: Washington, D.C., July 16, 1991.

Froehlich, D.C., 1989, Local scour at bridge abutments in Ports, M.A., ed., Hydraulic Engineering--Proceedings of the 1989 National Conference on Hydraulic Engineering: New York, American Society of Civil Engineers, p. 13-18.

Hayes, D.C.,1993, Site selection and collection of bridge-scour data in Delaware, Maryland, and Virginia: U.S. Geological Survey WaterResources Investigation Report 93-4017, 23 p.

Johnson, C.G. and Tasker, G.D.,1974, Progress report on flood magnitude and frequency of Vermont streams: U.S. Geological Survey Open-File Report 74-130, 37 p.

Lagasse, P.F., Schall, J.D., Johnson, F., Richardson, E.V., Richardson, J.R., Chang, F., 1991, Stream Stability at Highway Structures: Federal Highway Administration Hydraulic Engineering Circular No. 20, Publication FHWA-IP-90-014, 195 p.

Laursen, E.M., 1960, Scour at bridge crossings: Journal of the Hydraulics Division, American Society of Civil Engineers, v. 86, no. HY2, p. 39-53.

Richardson, E.V., Harrison, L.J., Richardson, J.R., and Davis, S.R., 1993, Evaluating scour at bridges: Federal Highway Administration Hydraulic Engineering Circular No. 18, Publication FHWA-IP-90-017, 131 p.

Richardson, E.V., Simons, D.B., and Julien, P.Y., 1990, Highways in the river environment: Federal Highway Administration Publication FHWA-HI-90-016.

Ritter, D.F., 1984, Process Geomorphology: W.C. Brown Co., Debuque, Iowa, 603 p.

Roberson, J.A., Cassidy, J.J., and Chaudhry, M.H., 1988, Hydraulic Engineering, Houghton Mifflin Company, Boston, 662 p.

Shearman, J.O., 1990, User's manual for WSPRO--a computer model for water surface profile computations: Federal Highway Administration Publication FHWA-IP-89-027, 187 p.

Shearman, J.O., Kirby, W.H., Schneider, V.R., and Flippo, H.N., 1986, Bridge waterways analysis model; research report: Federal Highway Administration Publication FHWA-RD-86-108, 112 p.

U.S. Department of Transportation, 1993, Stream stability and scour at highway bridges, Participant Workbook: Federal Highway Administration Publication FHWA HI-91-011.

U.S. Geological Survey, 1966, Plymouth, Vermont 7.5 Minute Series quadrangle map: U.S. Geological Survey Topographic Maps, Photoinspected 1983, Scale 1:24,000. 


\section{APPENDIX A: \\ WSPRO INPUT FILE}




\section{WSPRO INPUT FILE}

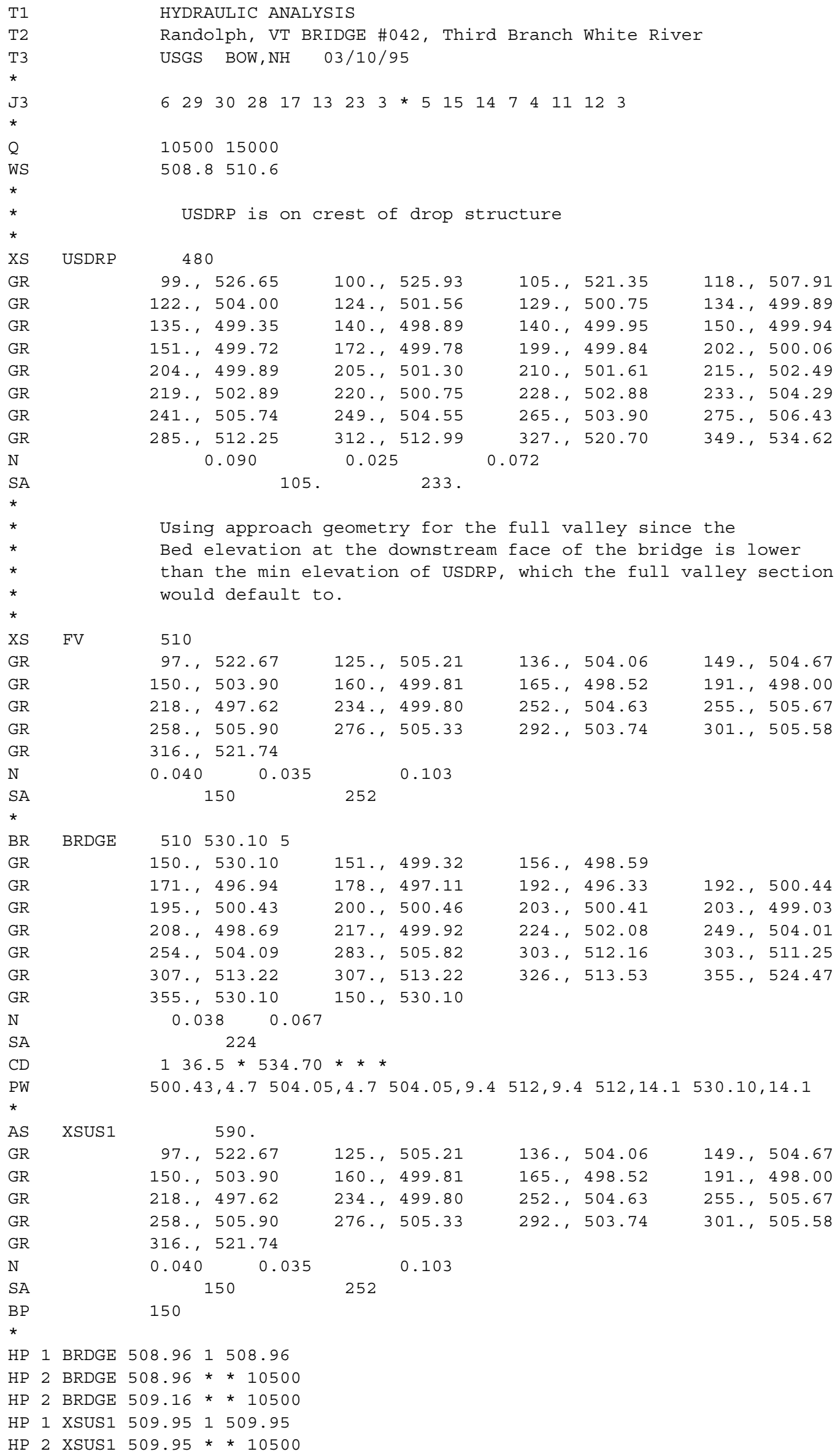




\section{APPENDIX B: \\ WSPRO OUTPUT FILE}


WSPRO OUTPUT FILE

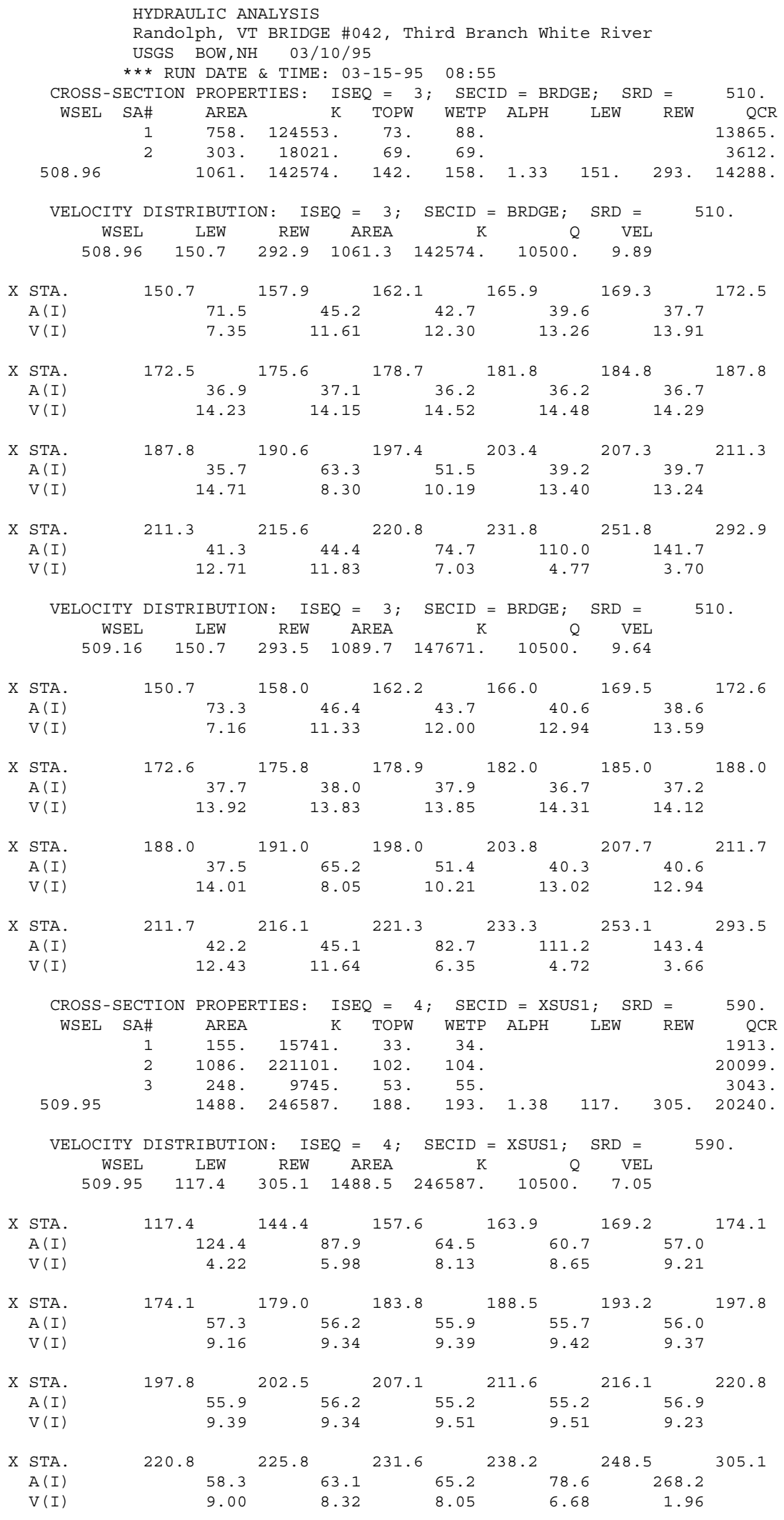


WSPRO OUTPUT FILE (continued)

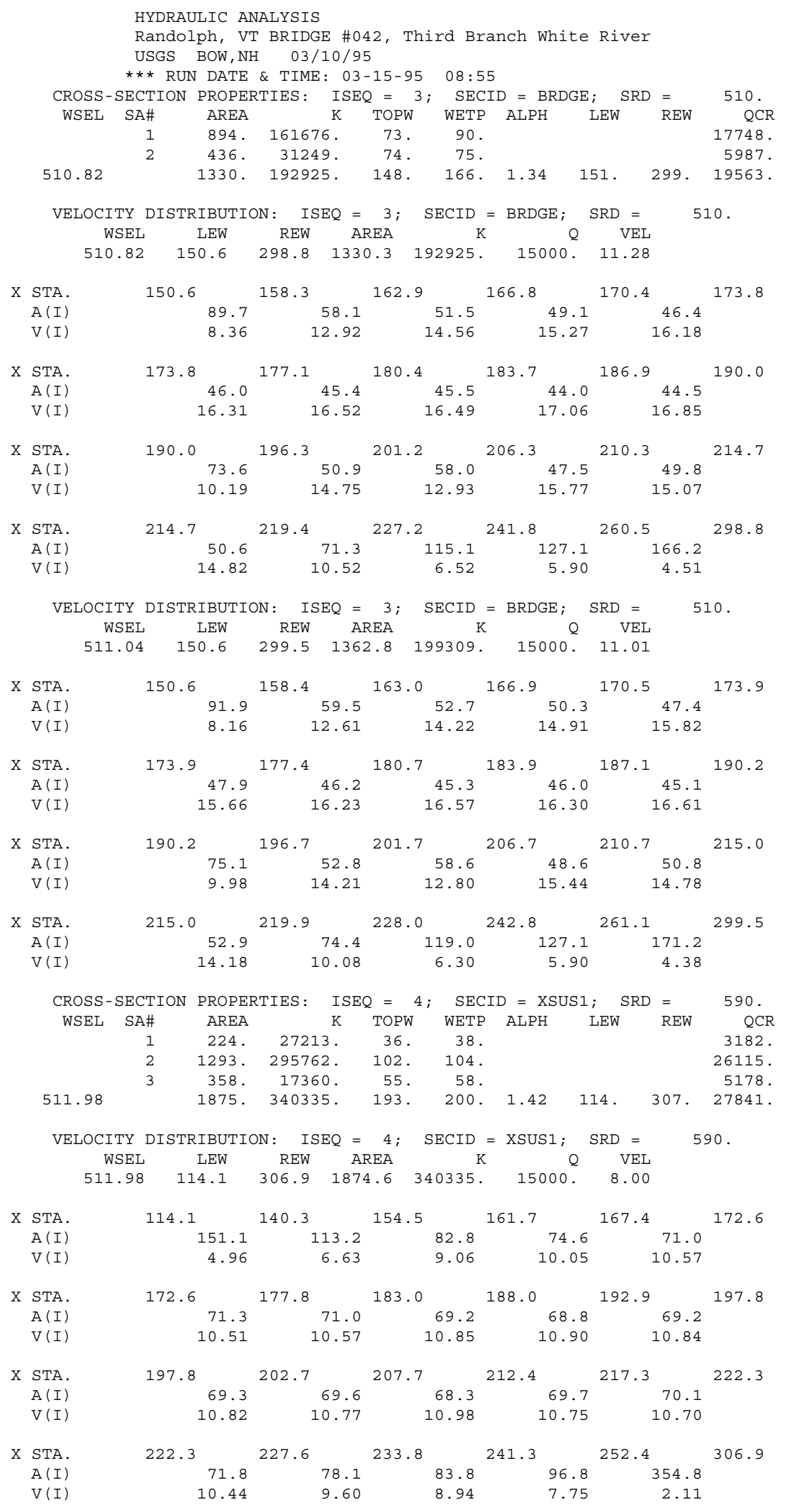


WSPRO OUTPUT FILE (continued)

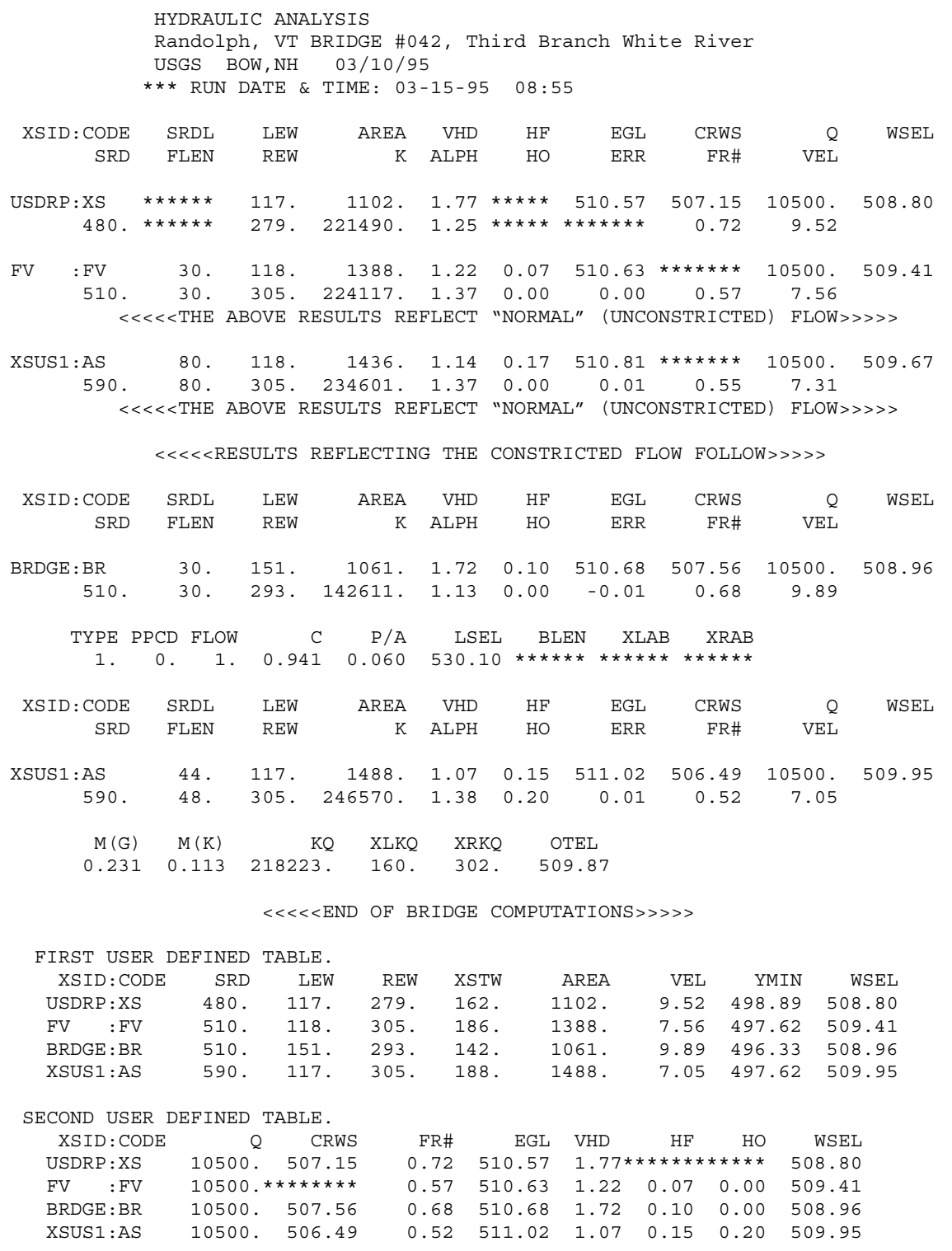


WSPRO OUTPUT FILE (continued)

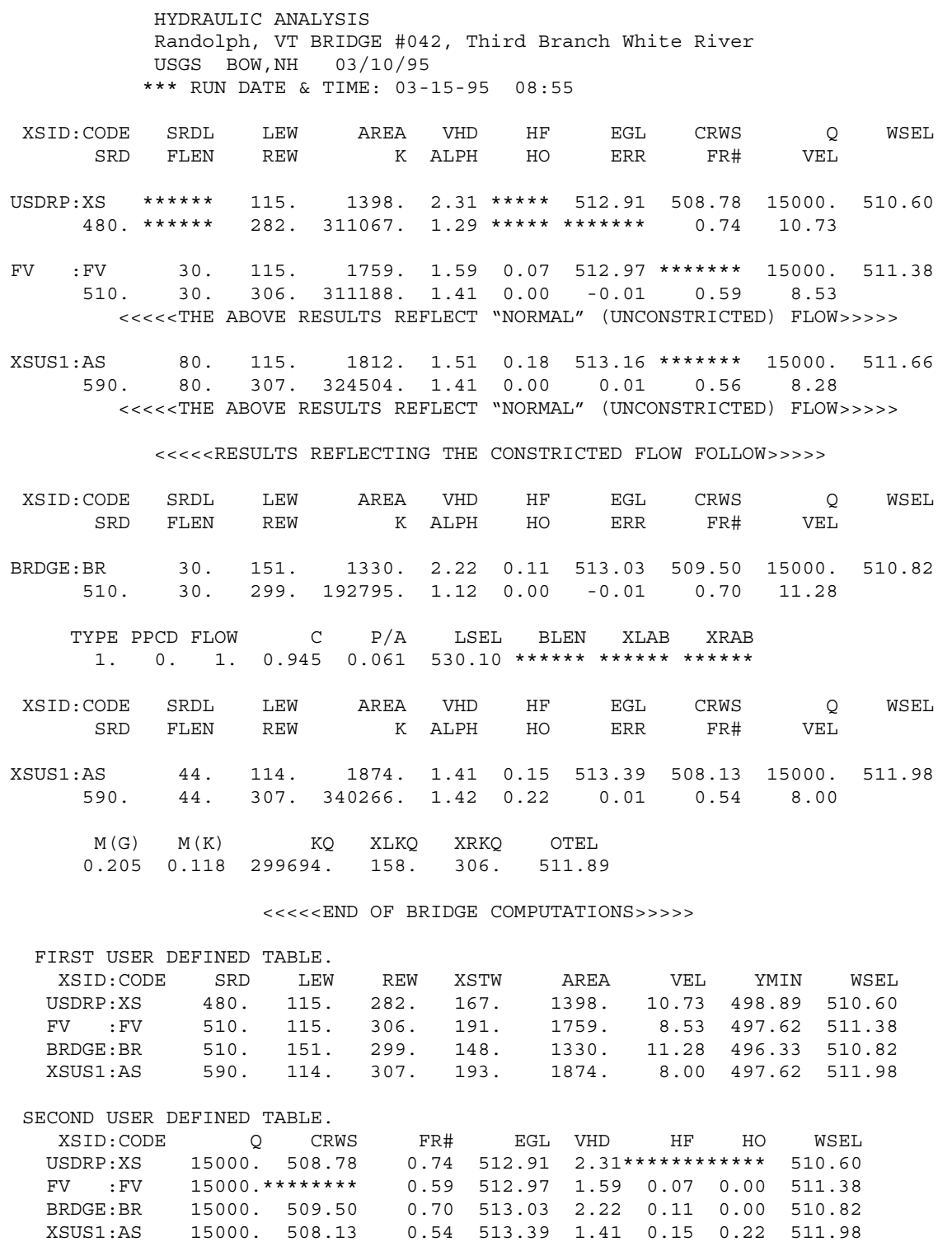




\section{APPENDIX C:}

\section{BED-MATERIAL PARTICAL-SIZE DISTRIBUTION}




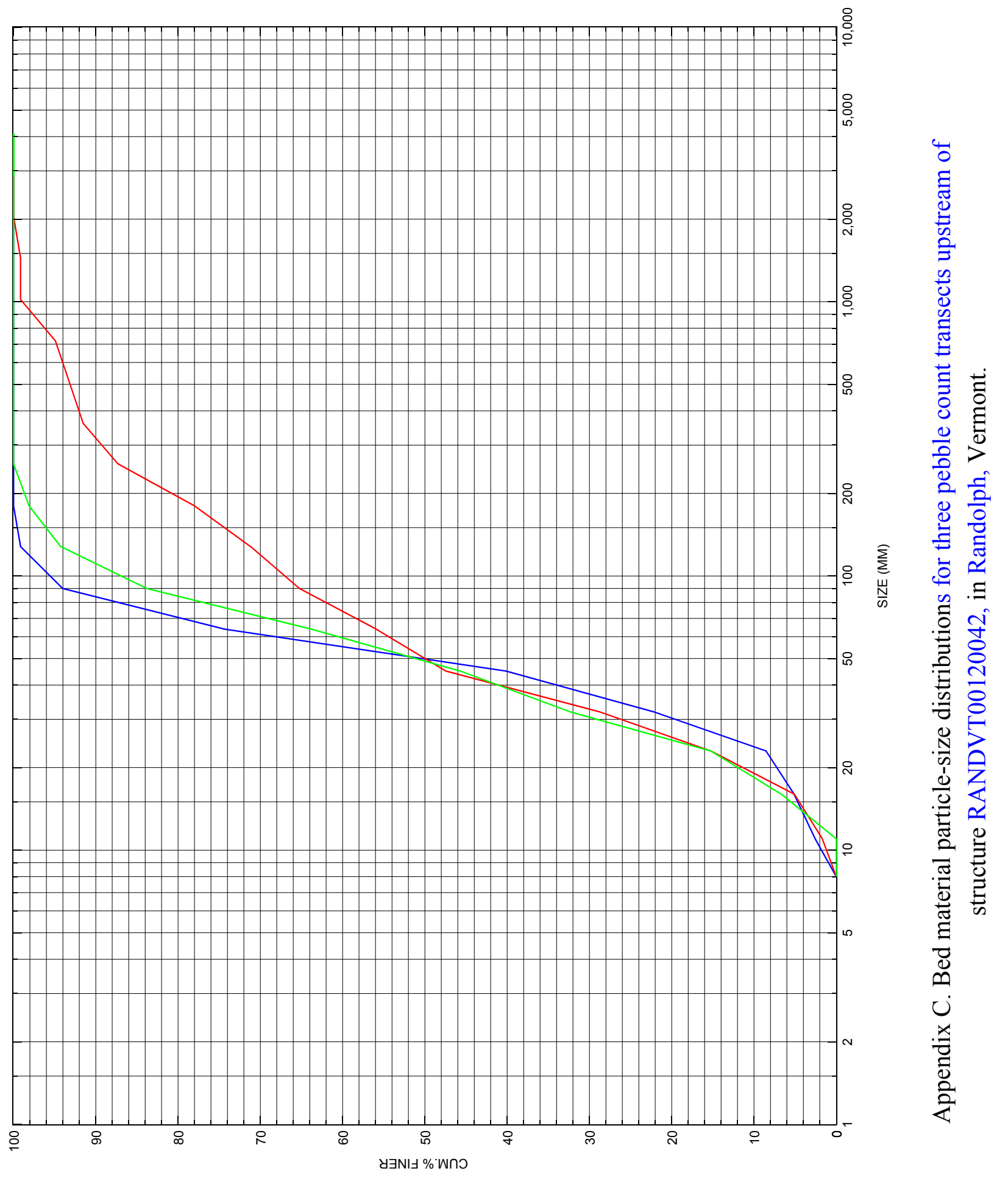




\section{APPENDIX D: \\ HISTORICAL DATA FORM}

